\section{Influence of Growing Area, Year, Season, and Cultivar on the Composition of Myrtle Leaves and Infusions}

\author{
Maurizio Mulas ${ }^{1}$ and Rita A.M. Melis \\ Department of Economics and Tree Systems, University of Sassari, \\ Sassari, Italy
}

Additional index words. liqueurs, color, polyphenols, chlorophyll, tannins

\begin{abstract}
Leaves of five myrtle cultivars were analyzed for chlorophyll $a$ and $b$, polyphenol, and tannin contents in two years (2000 and 2001), two seasons (spring and winter), and two growing areas (Alghero and Oristano, Sardinia, Italy). The hydroalcoholic leaf infusions obtained from the same cultivars were analyzed for the abovementioned compounds and for their chromatic values as well. $L^{*}$ chromatic component ranged from 44.22 to 49.94 , $a^{*}$ values ranged between -5.82 and -2.50 , and $b^{*}$ values ranged between 10.74 and 18.40 . The relationships between leaf and infusion characteristics were evaluated. Chlorophyll $a$ content ranged from 1.9 to $4.7 \mathrm{mg} \cdot \mathrm{g}^{-1}$ of dry weight in leaves and from 14.8 to $35.2 \mathrm{mg} \cdot \mathrm{L}^{-1}$ in infusions. Chlorophyll $b$ ranged between 0.3 and $2.9 \mathrm{mg} \cdot \mathrm{g}^{-1}$ of dry weight in leaves and between 3.4 to $12.1 \mathrm{mg} \cdot \mathrm{L}^{-1}$ in infusions. Polyphenols ranged between 6.8 and $15.3 \mathrm{~g} / 100 \mathrm{~g}$ of dry weight in leaves and between 2.6 and $13.9 \mathrm{~g} \cdot \mathrm{L}^{-1}$ in hydroalcoholic infusions. Tannins ranged from 140 to $516 \mathrm{mg} \cdot \mathrm{g}^{-1}$ of dry weight in leaves and from 57 to $291 \mathrm{mg} \cdot \mathrm{L}^{-1}$ in infusions. Significant interactions among year, growing area, season, and cultivar effects occurred for all leaf and infusion parameters, except for leaf chlorophyll $a$. Strong correlations between leaf and infusion composition were not found. Because infusion quality was little influenced by the studied variables, to the best of our knowledge, winter harvest of myrtle leaves for white myrtle liqueur is feasible.
\end{abstract}

Myrtle (Myrtus communis L.) is a shrub of the Myrtaceae family. It is a thermophylous species growing spontaneously in the Mediterranean area (Mulas et al., 1998). Since ancient times, this species have been used for medicinal and aromatic purposes because of the essential oil content of its leaves and fruits (Dorman and Deans, 2000; Shadidi Bonjar, 2004; Vanhaelen and Vanhaelen-Fastré, 1980).

In Sardinia, myrtle berries and leaves are traditionally used in the production of red and white myrtle liqueurs, respectively (Alamanni and Cossu, 2004; Mulas et al., 2002a). In the last decades, the production of myrtle liqueurs has increased from a homemade to an industrial level. The production of myrtle liqueur, which is still increasing, has already reached 3 million liters per year (Mulas and Cani, 1999).

The industrial production of myrtle liqueur follows a traditional recipe and technique, and consumers are attracted by the image of genuineness of these drinks. Myrtle liqueur is produced by the hydroalcoholic infusion of berries or leaves and the addition

Received for publication 6 July 2007. Accepted for publication 24 Oct. 2007.

The research was supported by the Ministero delle Politiche Agricole e Forestali of Italy (special grant IPPO) and by the Regione Autonoma della Sardegna. ${ }^{1}$ To whom reprint requests should be addressed; e-mail maurimulas@tiscali.it of a sugary solution, without using any antioxidant or conservant. The production of white myrtle liqueur involves a treatment of clarification that prevents its darkening by the oxidation of exceeding phenolic compounds. Fortunately, the beneficial properties of myrtle leaf extracts are not damaged by this treatment (Alamanni and Cossu, 2004; Romani et al., 1999; Rosa et al., 2003; Romani et al., 2004).

Thus far, leaves and fruits used by distilleries have been hand-picked from wild myrtle plants. This practice may alter the ecological equilibrium of natural ecosystems and does not assure quality standards of the raw material supplied to the industry (Mulas et al., 1999).

In the last few years, the study of natural myrtle ecotypes has started to obtain adequate plant material for its cultivation. After the morphological and biometric characterization of spontaneous myrtle shrubs (Mulas and Cani, 1999; Mulas et al., 1998), several myrtle cultivars have been selected (Mulas et al., 2002a; 2002b). Other studies on spontaneous myrtle plants have focused on their polyphenol compounds (Hinou et al., 1988) and essential oil yield and composition (Boelens and Jimenez, 1992; Bradesi et al., 1997; Gauthier et al., 1988; Özcan and Chalchat, 2004; Weyerstahl et al., 1994; Vanhaelen and Vanhaelen-Fastré, 1980). The antioxidant (Demo et al., 1998), antibacterial (Al-Saimary et al., 2002; Dulger and Gonuz, 2004; Milhau et al., 1997; Shadidi Bonjar and Karimi, 2004), antifungal, antiviral (Zolfaghari et al., 1997), and insecticide properties of leaf extracts from wild myrtle plants (Traboulsi et al., 2002) have also been demonstrated.

The content of chlorophyll $a$ and $b$, tannins, and polyphenols of myrtle leaves and myrtle liqueurs are important attributes. In particular, chlorophylls ( $a$ and $b$ ) give an attractive pale green color to myrtle liqueur, tannins are responsible for its astringency, and polyphenols are related to a spicy taste and brown color after its oxidation. However, little information is available on the characteristics of leaves of cultivated plants and on the relationship between myrtle leaf composition and liqueur quality.

For this reason, the leaves of five myrtle cultivars growing in two sites of Sardinia were analyzed after spring and winter samplings for chlorophyll, polyphenol, and tannin contents in 2000 and 2001. The hydroalcoholic infusions obtained from their leaves were analyzed for the same compounds and for their color as well.

\section{Materials and Methods}

Plant material. In the spring and winter of 2000 and 2001, leaves were sampled from cv Nadia, cv Marta, cv Daniela, cv Tonina, and cv Grazia myrtle plants growing in two experimental plots located in Alghero $\left(40^{\circ} 39^{\prime} \mathrm{N}, 8^{\circ} 21^{\prime} \mathrm{E}, 39 \mathrm{~m}\right.$ a.s.1.) and Oristano $\left(39^{\circ} 53^{\prime} \mathrm{N}, 8^{\circ} 37^{\prime} \mathrm{E}, 12 \mathrm{~m}\right.$ a.s.l.). The rainfall and air temperatures of the two growing areas in the two years recorded at a nearby station are reported in Fig. 1.

Each studied cultivar consisted of about 100 bushes planted in a single row at a spacing of $1 \mathrm{~m}$ within rows and $3 \mathrm{~m}$ between rows. Weeds were mechanically removed and myrtle plants were watered by drip irrigation during the summer.

For each cultivar, three random samples of $200 \mathrm{~g}$ of mature leaves were hand picked before bloom (May and June 2000 and 2001) and after berry ripening time (Nov. and Dec. 2000 and 2001) from all plants for a total of about $600 \mathrm{~g}$ of leaves per cultivar. Leaves were stored in plastic bags at $-22{ }^{\circ} \mathrm{C}$ until chemical analysis or infusion in the hydroalcoholic solution. The infusion was performed in laboratory following the industrial process guidelines. A random sample of leaves of each cultivar $(20 \mathrm{~g})$ was put separately in a glass jar containing $120 \mathrm{~mL}$ of $96 \%$ ethanol and $60 \mathrm{~mL}$ of deionized water. The infusion was kept in a dark place at room temperature for 3 months.

Polyphenol extraction. Leaf phenolic compounds were extracted according to Congiu and Franco (1998). Frozen leaves (10 g) were crushed and mixed in $100 \mathrm{~mL}$ of methanol containing $0.1 \%$ of $\mathrm{HCl}$ for $24 \mathrm{~h}$ at $4{ }^{\circ} \mathrm{C}$. After filtration through filter paper, the solution was adjusted to $100 \mathrm{~mL}$ with acidified methanol and was stored in dark glass bottles at $4{ }^{\circ} \mathrm{C}$ until analysis. 

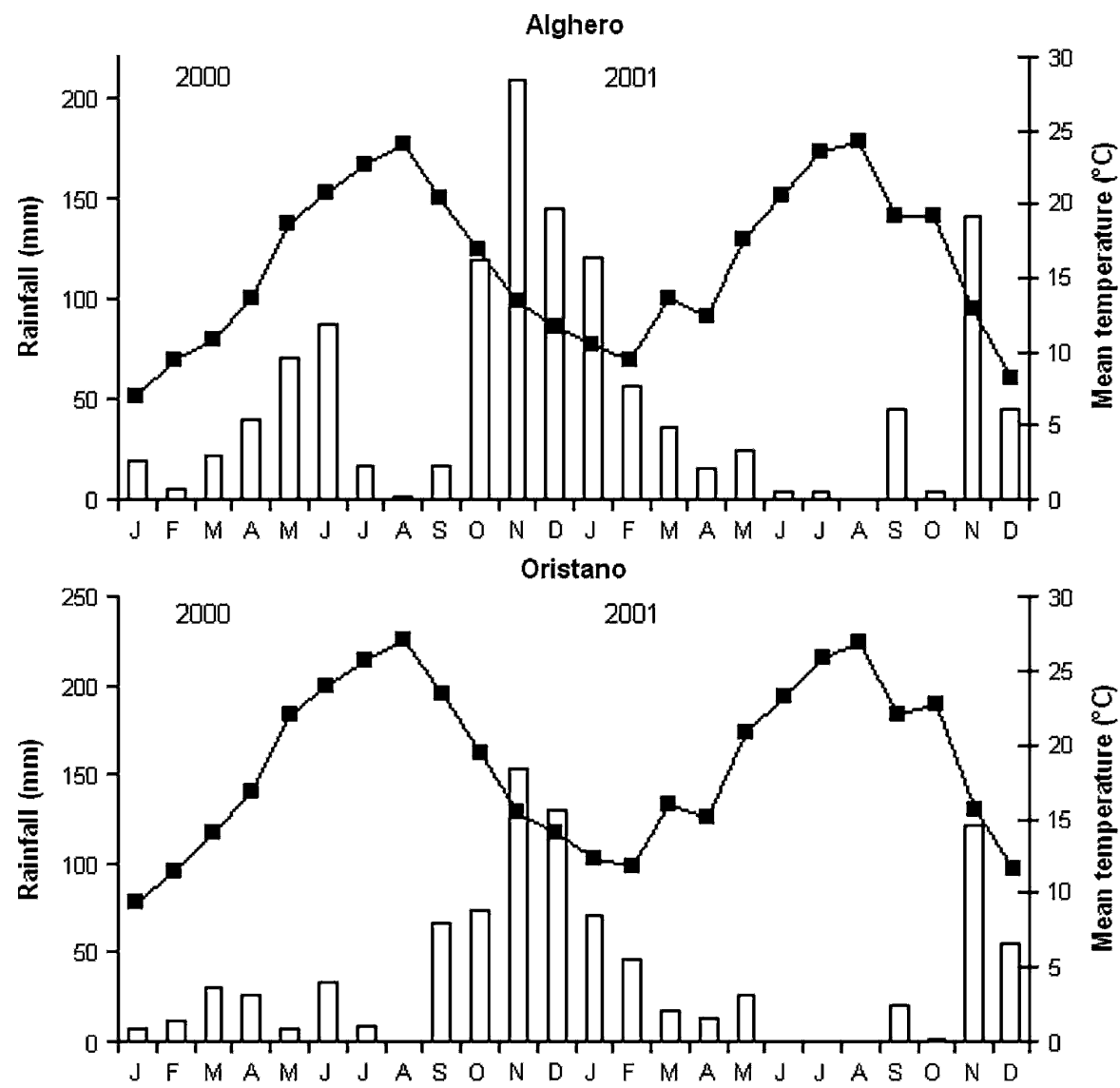

Fig. 1. Monthly rainfall (bars) and mean air temperature (lines) in Alghero and Oristano in 2000 and 2001.

Table 1. Chlorophyll $a$ and $b$ content in myrtle leaves from cultivated plants. Each value is the mean of three replications. Mean separation was performed by Duncan's multiple range test. Data labeled with the same letter are not significantly different at $P \leq 0.01$.

\begin{tabular}{lccccccc}
\hline \multicolumn{7}{c}{ Chlorophyll $a\left(\mathrm{mg} \cdot \mathrm{g}^{-1}\right.$ leaf dry wt) } \\
\hline \multirow{7}{*}{ Area } & Year & Season & Nadia & Marta & Daniela & Tonina & Grazia \\
\hline Alghero & 2000 & Spring & $3.37 \mathrm{bcd}$ & $3.59 \mathrm{bc}$ & $2.75 \mathrm{c}-\mathrm{f}$ & $2.75 \mathrm{c}-\mathrm{f}$ & $4.71 \mathrm{a}$ \\
& 2000 & Winter & $2.89 \mathrm{~b}-\mathrm{f}$ & $2.11 \mathrm{def}$ & $2.02 \mathrm{ef}$ & $2.97 \mathrm{~b}-\mathrm{f}$ & $2.25 \mathrm{def}$ \\
& 2001 & Spring & $2.79 \mathrm{c}-\mathrm{f}$ & $2.48 \mathrm{c}-\mathrm{f}$ & $3.25 \mathrm{~b}-\mathrm{e}$ & $4.06 \mathrm{ab}$ & $2.76 \mathrm{c}-\mathrm{f}$ \\
& 2001 & Winter & $2.96 \mathrm{~b}-\mathrm{f}$ & $2.79 \mathrm{c}-\mathrm{f}$ & $2.79 \mathrm{c}-\mathrm{f}$ & $3.28 \mathrm{~b}-\mathrm{e}$ & $2.62 \mathrm{c}-\mathrm{f}$ \\
Oristano & 2000 & Spring & $2.35 \mathrm{c}-\mathrm{f}$ & $2.74 \mathrm{c}-\mathrm{f}$ & $1.85 \mathrm{f}$ & $2.35 \mathrm{c}-\mathrm{f}$ & $3.05 \mathrm{~b}-\mathrm{f}$ \\
& 2000 & Winter & $2.40 \mathrm{c}-\mathrm{f}$ & $2.88 \mathrm{~b}-\mathrm{f}$ & $2.15 \mathrm{def}$ & $2.98 \mathrm{~b}-\mathrm{f}$ & $2.67 \mathrm{c}-\mathrm{f}$ \\
& 2001 & Spring & $3.09 \mathrm{~b}-\mathrm{f}$ & $2.93 \mathrm{~b}-\mathrm{f}$ & $2.77 \mathrm{c}-\mathrm{f}$ & $3.37 \mathrm{bcd}$ & $2.95 \mathrm{~b}-\mathrm{f}$ \\
& 2001 & Winter & $2.44 \mathrm{c}-\mathrm{f}$ & $2.89 \mathrm{~b}-\mathrm{f}$ & $2.54 \mathrm{c}-\mathrm{f}$ & $3.00 \mathrm{~b}-\mathrm{f}$ & $3.02 \mathrm{~b}-\mathrm{f}$ \\
& & & & & & \\
Alghero & 2000 & Spring & $1.76 \mathrm{bcd}$ & $2.01 \mathrm{~b}$ & $1.37 \mathrm{~b}-\mathrm{g}$ & $1.00 \mathrm{~d}-\mathrm{i}$ & $2.85 \mathrm{a}$ \\
& 2000 & Winter & $1.05 \mathrm{c}-\mathrm{i}$ & $1.06 \mathrm{c}-\mathrm{i}$ & $0.31 \mathrm{i}$ & $1.02 \mathrm{~d}-\mathrm{i}$ & $0.82 \mathrm{f}-\mathrm{i}$ \\
& 2001 & Spring & $1.49 \mathrm{~b}-\mathrm{f}$ & $1.35 \mathrm{~b}-\mathrm{g}$ & $0.52 \mathrm{hi}$ & $1.81 \mathrm{bc}$ & $1.62 \mathrm{~b}-\mathrm{e}$ \\
& 2001 & Winter & $1.19 \mathrm{c}-\mathrm{h}$ & $1.13 \mathrm{c}-\mathrm{h}$ & $1.36 \mathrm{~b}-\mathrm{g}$ & $1.64 \mathrm{~b}-\mathrm{e}$ & $1.63 \mathrm{~b}-\mathrm{e}$ \\
Oristano & 2000 & Spring & $0.72 \mathrm{f}-\mathrm{i}$ & $0.87 \mathrm{e}-\mathrm{i}$ & $0.56 \mathrm{hi}$ & $0.73 \mathrm{f}-\mathrm{i}$ & $1.06 \mathrm{c}-\mathrm{i}$ \\
& 2000 & Winter & $1.12 \mathrm{c}-\mathrm{h}$ & $0.99 \mathrm{~d}-\mathrm{i}$ & $0.65 \mathrm{ghi}$ & $1.11 \mathrm{c}-\mathrm{h}$ & $0.96 \mathrm{e}-\mathrm{i}$ \\
& 2001 & Spring & $1.44 \mathrm{~b}-\mathrm{f}$ & $1.03 \mathrm{c}-\mathrm{i}$ & $1.06 \mathrm{c}-\mathrm{i}$ & $1.22 \mathrm{c}-\mathrm{h}$ & $1.16 \mathrm{c}-\mathrm{h}$ \\
& 2001 & Winter & $1.10 \mathrm{c}-\mathrm{h}$ & $1.31 \mathrm{~b}-\mathrm{h}$ & $0.93 \mathrm{e}-\mathrm{i}$ & $1.36 \mathrm{~b}-\mathrm{g}$ & $1.04 \mathrm{c}-\mathrm{i}$ \\
\hline
\end{tabular}

Total polyphenol analysis. One milliliter of methanolic leaf extract, pure or diluted (usually 1:10, but variable according to the expected polyphenol concentration), was transferred into a flask and $35 \mathrm{~mL}$ of deionized water and $2.5 \mathrm{~mL}$ of Folin-Ciocalteus reagent (Merck, Withehouse Station, NJ) were added. After $3 \mathrm{~min}, 5 \mathrm{~mL}$ of $20 \%$ optic glass cuvettes. Absorbance at $750 \mathrm{~nm}$ wavelength was measured by a Cary $1 \mathrm{E}$ spectrophotometer (Varian, Palo Alto, CA).

Increasing concentrations of a standard of pure $(+)$ catechine (Fluka grade, St. Gallen, Switzerland) were used to calculate the polyphenol content of the leaf extracts and infusions.

Tannin analysis. Four milliliters of diluted leaf methanolic extract or pure hydroalcoholic infusions was put in a flask. Four milliliters of vanillin reagent ( $1 \%$ vanillin in $70 \%$ sulfuric acid) and $2 \mathrm{~mL}$ of $96 \%$ ethanol were then added to it. After being kept for $20 \mathrm{~min}$ in the dark, the absorbance at $500 \mathrm{~nm}$ wavelength was measured by spectrophotometry. A reference of $6 \mathrm{~mL}$ of $96 \%$ ethanol and $4 \mathrm{~mL}$ of vanillin was used. Tannin concentration was determined by comparison with a reference of increasing $(+)$ catechine concentrations.

Chlorophyll analysis. Chlorophyll $a$ and $b$ content in leaf tissues was determined according to the method proposed by Inskeeo and Bloom (1985). Twenty disks of 1-cm diameter were removed from the leaves, weighed, and put in hermetically closed flasks containing $10 \mathrm{~mL}$ of $80 \%$ acetone. After $48 \mathrm{~h}$ of incubation in the dark at $4{ }^{\circ} \mathrm{C}$, samples were homogenized by a Diax 600 omnimixer (Heidolph, Kelheim-Donau, Germany) and subsequently filtered. Hydroalcoholic infusions were diluted at 1:10 using $80 \%$ acetone.

Absorbance was measured at 664.5 and $647.0 \mathrm{~nm}$ wavelengths for chlorophyll $a$ and $b$, respectively, using a Cary 1 E spectrophotometer (Varian).

Color evaluation. The Commission Internationale de l'Eclairage (1976) L*, a*, and b* color coordinate values of the hydroalcoholic infusions were measured. $\mathrm{L}^{*}$ is the brightness of the color (the smallest $L^{*}$ yields black), a* is the red/green hue component $\left(+\mathrm{a}^{*}\right.$ is red, $-a^{*}$ is green), and $b^{*}$ is the blue/yellow hue component $\left(+b^{*}\right.$ is yellow, $-b^{*}$ is blue).

Two milliliters of infusion was put into a quartz cuvette and its chromatic values were measured by a Cary $1 \mathrm{E}$ spectrophotometer (Varian), within the range of 780 to $380 \mathrm{~nm}$ at 5-nm intervals.

Statistical analysis. All data were the average of three replications. Data were tested by analysis of variance with year, growing area, season, and cultivar as factors. Mean separation was performed by Duncan's multiple range test at $P \leq 0.01$, using MSTAT-C (Michigan State University, East Lansing, 1991) software.

\section{Results}

In Alghero, the year 2000 was charactersodium carbonate solution was added and the solution was shacked quickly. The solution was then heated and kept at $70{ }^{\circ} \mathrm{C}$ in a thermostatic bath for $20 \mathrm{~min}$, to allow it to become colored. After a fast refrigeration (about 2 min under water flux), the solution was filtered through a 120-mesh filter paper (Whatman, Brentford, UK) and introduced in zed by a total rainfall of $750 \mathrm{~mm}$, a minimum temperature in the coldest month (January) of $-2.7^{\circ} \mathrm{C}$, and a maximum temperature in the hottest month (August) of $40{ }^{\circ} \mathrm{C}$ (Fig. 1). In 2001, the same location had a total rainfall of $492 \mathrm{~mm}$, a minimum temperature in the coldest month (February) of $-3.1^{\circ} \mathrm{C}$, and a 
maximum temperature in the hottest month (August) of $38.2{ }^{\circ} \mathrm{C}$.

In Oristano, the year 2000 was characterized by a total rainfall of $549 \mathrm{~mm}$, a minimum temperature in the coldest month (January) of $1.0^{\circ} \mathrm{C}$, and a maximum temperature in the hottest month (August) of $44^{\circ} \mathrm{C}$. In 2001, that location showed a total rainfall of $373 \mathrm{~mm}$, a minimum temperature in the coldest month (February) of $0.0^{\circ} \mathrm{C}$, and a maximum temperature in the hottest month (August) of $40.3{ }^{\circ} \mathrm{C}$.

Mean temperatures were relatively similar in the two locations.

The composition of leaves and hydroalcoholic infusions in different years, growing areas, seasons, and myrtle cultivars is presented in Tables 1 through 5. The correlation coefficients between leaves and infusions for all measured parameters are presented in Table 6.

In the analysis of variance, the interactions among year, growing area, season, and cultivar were significant for all studied parameters, except for leaf chlorophyll $a$, which was influenced by year $\times$ growing area $\times$ season and year $\times$ season $\times$ cultivar interactions (data not shown).

Chlorophylls. Leaf chlorophyll $a$ content ranged between 1.9 and $4.7 \mathrm{mg} \cdot \mathrm{g}^{-1}$ of leaf dry weight (Table 1). The highest content of leaf chlorophyll $a$ was observed for cv Grazia in the Spring of 2000 in Alghero, followed by cv Tonina in the Spring of 2001 in the same growing area. The lowest leaf chlorophyll $a$ content was observed for cv Daniela in the Spring of 2000 in Oristano.

Leaf chlorophyll $b$ content ranged between 0.3 and $2.9 \mathrm{mg} \cdot \mathrm{g}^{-1}$ of leaf dry weight (Table 1). Leaves of cv Grazia showed the highest value of chlorophyll $b$ in the Spring of 2000 in Alghero, whereas the leaves of $\mathrm{cv}$ Daniela showed the lowest content in the winter of 2000 in the same location.

Infusion chlorophyll $a$ contents ranged between 14.8 and $35.2 \mathrm{mg} \cdot \mathrm{L}^{-1}$ and infusion chlorophyll $b$ content ranged from 3.4 and $12.1 \mathrm{mg} \cdot \mathrm{L}^{-1}$ (Table 2). The highest infusion chlorophyll contents were observed for $\mathrm{cv}$ Nadia in the winter of 2001 in Oristano and the lowest ones for cv Daniela in the Spring of 2000 in Oristano. When significant differences in chlorophylls were observed within the same cultivar, year, and location, the infusions obtained from leaves picked in winter were richer in chlorophylls.

Tannins. Tannin content ranged between 140 and $516 \mathrm{mg} / 100 \mathrm{~g}$ of leaf dry weight (Table 3). The minimum value was recorded for cv Grazia in the Winter 2001 in Oristano, whereas the maximum was registered for $\mathrm{cv}$ Tonina in the Spring 2001 in the same location.

Infusion tannins ranged from 57 to 291 $\mathrm{mg} \cdot \mathrm{L}^{-1}$ (Table 4). Leaves of cv Daniela picked in the Winter of 2001 in Alghero produced an infusion with the highest content of tannins, whereas the infusion made from leaves of cv Tonina harvested in the Winter of 2000 in Oristano had the lowest tannin content.

Polyphenols. Leaf polyphenol content ranged between 6.8 and $15.3 \mathrm{~g} / 100 \mathrm{~g}$ of dry

Table 2. Chlorophyll $a$ and $b$ content in infusions of myrtle leaves from cultivated plants. Each value is the mean of three replications. Mean separation was performed by Duncan's multiple range test. Data labeled with the same letter are not significantly different at $P \leq 0.01$.

Chlorophyll $a\left(\mathrm{mg} \cdot \mathrm{L}^{-1}\right.$ infusion)

\begin{tabular}{|c|c|c|c|c|c|c|c|}
\hline \multirow[b]{2}{*}{ Area } & \multirow[b]{2}{*}{ Yr } & \multirow[b]{2}{*}{ Season } & \multicolumn{5}{|c|}{ Cultivar } \\
\hline & & & Nadia & Marta & Daniela & Tonina & Grazia \\
\hline \multirow{4}{*}{ Alghero } & 2000 & Spring & $20.11 \mathrm{e}-\mathrm{j}$ & 15.96 hij & $14.79 \mathrm{j}$ & $19.81 \mathrm{e}-\mathrm{j}$ & $18.80 \mathrm{e}-\mathrm{j}$ \\
\hline & 2000 & Winter & $31.41 \mathrm{abc}$ & $24.15 \mathrm{~b}-\mathrm{i}$ & $25.37 \mathrm{~b}-\mathrm{g}$ & $26.90 \mathrm{a}-\mathrm{f}$ & $19.65 \mathrm{e}-\mathrm{j}$ \\
\hline & 2001 & Spring & $20.87 \mathrm{~d}-\mathrm{j}$ & $17.49 \mathrm{~g}-\mathrm{j}$ & $18.35 \mathrm{f}-\mathrm{j}$ & $19.06 \mathrm{e}-\mathrm{j}$ & $18.98 \mathrm{e}-\mathrm{j}$ \\
\hline & 2001 & Winter & $24.02 \mathrm{~b}-\mathrm{j}$ & $21.76 \mathrm{~d}-\mathrm{j}$ & $25.20 \mathrm{~b}-\mathrm{h}$ & $32.44 \mathrm{ab}$ & $27.05 \mathrm{a}-\mathrm{f}$ \\
\hline \multirow[t]{4}{*}{ Oristano } & 2000 & Spring & $21.08 \mathrm{~d}-\mathrm{j}$ & $17.90 \mathrm{f}-\mathrm{j}$ & $14.77 \mathrm{j}$ & $18.29 \mathrm{f}-\mathrm{j}$ & $15.58 \mathrm{ij}$ \\
\hline & 2000 & Winter & $19.46 \mathrm{e}-\mathrm{j}$ & $19.10 \mathrm{e}-\mathrm{j}$ & $22.76 \mathrm{c}-\mathrm{j}$ & $23.68 \mathrm{~b}-\mathrm{j}$ & $16.85 \mathrm{~g}-\mathrm{j}$ \\
\hline & 2001 & Spring & $20.69 \mathrm{e}-\mathrm{j}$ & $19.68 \mathrm{e}-\mathrm{j}$ & $16.68 \mathrm{~g}-\mathrm{j}$ & $18.82 \mathrm{e}-\mathrm{j}$ & $18.12 \mathrm{f}-\mathrm{j}$ \\
\hline & 2001 & Winter & $35.16 \mathrm{a}$ & $29.65 \mathrm{a}-\mathrm{d}$ & $29.72 \mathrm{a}-\mathrm{d}$ & $20.25 \mathrm{e}-\mathrm{j}$ & $27.97 \mathrm{a}-\mathrm{e}$ \\
\hline \multicolumn{8}{|c|}{ Chlorophyll $b$ (mg $\cdot \mathrm{L}^{-1}$ infusion) } \\
\hline \multirow[t]{4}{*}{ Alghero } & 2000 & Spring & $4.67 \mathrm{f}-\mathrm{i}$ & $3.33 \mathrm{i}$ & $3.64 \mathrm{hi}$ & $4.78 \mathrm{f}-\mathrm{i}$ & $5.11 \mathrm{f}-\mathrm{i}$ \\
\hline & 2000 & Winter & $8.09 \mathrm{~b}-\mathrm{f}$ & $6.58 \mathrm{c}-\mathrm{i}$ & $5.83 \mathrm{e}-\mathrm{i}$ & $6.52 \mathrm{c}-\mathrm{i}$ & $4.00 \mathrm{hi}$ \\
\hline & 2001 & Spring & $4.48 \mathrm{ghi}$ & $4.06 \mathrm{hi}$ & $4.22 \mathrm{hi}$ & $4.68 \mathrm{f}-\mathrm{i}$ & $4.70 \mathrm{f}-\mathrm{i}$ \\
\hline & 2001 & Winter & $7.15 \mathrm{~b}-\mathrm{h}$ & $7.90 \mathrm{~b}-\mathrm{g}$ & $9.31 \mathrm{a}-\mathrm{d}$ & $10.17 \mathrm{ab}$ & $8.61 \mathrm{~b}-\mathrm{e}$ \\
\hline \multirow[t]{4}{*}{ Oristano } & 2000 & Spring & $6.36 \mathrm{c}-\mathrm{i}$ & $3.48 \mathrm{i}$ & $3.35 \mathrm{i}$ & $4.08 \mathrm{hi}$ & $3.44 \mathrm{i}$ \\
\hline & 2000 & Winter & $4.20 \mathrm{hi}$ & $3.59 \mathrm{hi}$ & $5.18 \mathrm{f}-\mathrm{i}$ & $5.68 \mathrm{e}-\mathrm{i}$ & $3.55 \mathrm{hi}$ \\
\hline & 2001 & Spring & $4.81 \mathrm{f}-\mathrm{i}$ & 4.54 ghi & $3.78 \mathrm{hi}$ & $3.89 \mathrm{hi}$ & $4.15 \mathrm{hi}$ \\
\hline & 2001 & Winter & $12.0 \mathrm{a}$ & $8.88 \mathrm{a}-\mathrm{e}$ & $9.11 \mathrm{a}-\mathrm{e}$ & $6.08 \mathrm{~d}-\mathrm{i}$ & $9.67 \mathrm{abc}$ \\
\hline
\end{tabular}

Table 3. Tannins and polyphenols content in myrtle leaves from cultivated plants. Each value is the mean of three replications. Mean separation was performed by Duncan's multiple range test. Data labeled with the same letter are not significantly different at $P \leq 0.01$.

\begin{tabular}{|c|c|c|c|c|c|c|c|}
\hline \multicolumn{8}{|c|}{ Tannins (mg/100g leaf dry wt) } \\
\hline \multirow[b]{2}{*}{ Area } & \multirow[b]{2}{*}{ Yr } & \multirow[b]{2}{*}{ Season } & \multicolumn{5}{|c|}{ Cultivar } \\
\hline & & & Nadia & Marta & Daniela & Tonina & Grazia \\
\hline \multirow[t]{4}{*}{ Alghero } & 2000 & Spring & $183 \mathrm{o}-\mathrm{s}$ & $212 \mathrm{~m}-\mathrm{r}$ & 159 qrs & $170 \mathrm{p}-\mathrm{s}$ & $224 \mathrm{~m}-\mathrm{p}$ \\
\hline & 2000 & Winter & $316 \mathrm{ijk}$ & $474 \mathrm{ab}$ & $285 \mathrm{jkl}$ & $271 \mathrm{klm}$ & $211 \mathrm{~m}-\mathrm{r}$ \\
\hline & 2001 & Spring & $385 \mathrm{e}-\mathrm{h}$ & $481 \mathrm{ab}$ & 335 hij & $363 \mathrm{f}-\mathrm{i}$ & $2401-0$ \\
\hline & 2001 & Winter & 315 ijk & $431 \mathrm{~b}-\mathrm{e}$ & $384 \mathrm{e}-\mathrm{h}$ & $318 \mathrm{ijk}$ & $448 \mathrm{bcd}$ \\
\hline \multirow[t]{4}{*}{ Oristano } & 2000 & Spring & 350 ghi & $246 \mathrm{lmn}$ & $218 \mathrm{~m}-\mathrm{q}$ & $2311-0$ & $272 \mathrm{klm}$ \\
\hline & 2000 & Winter & $314 \mathrm{ijk}$ & $2401-0$ & $414 \mathrm{c}-\mathrm{f}$ & $464 \mathrm{abc}$ & $473 \mathrm{ab}$ \\
\hline & 2001 & Spring & $398 \mathrm{~d}-\mathrm{g}$ & $513 \mathrm{a}$ & $482 \mathrm{ab}$ & 516 a & $461 \mathrm{abc}$ \\
\hline & 2001 & Winter & $251 \mathrm{lmn}$ & $157 \mathrm{rs}$ & $209 n-r$ & $185 \mathrm{o}-\mathrm{S}$ & $140 \mathrm{~s}$ \\
\hline \multicolumn{8}{|c|}{ Polyphenols (g/100g leaf dry wt) } \\
\hline \multirow[t]{4}{*}{ Alghero } & 2000 & Spring & $11.1 \mathrm{~d}-\mathrm{g}$ & $10.7 \mathrm{e}-\mathrm{j}$ & $9.2 \mathrm{~h}-\mathrm{m}$ & $8.5 \mathrm{k}-\mathrm{n}$ & $10.7 \mathrm{~d}-\mathrm{j}$ \\
\hline & 2000 & Winter & $13.3 \mathrm{bc}$ & $14.2 \mathrm{ab}$ & $7.7 \mathrm{mn}$ & $6.8 \mathrm{n}$ & $10.9 \mathrm{~d}-\mathrm{i}$ \\
\hline & 2001 & Spring & $10.4 \mathrm{e}-\mathrm{j}$ & $13.9 \mathrm{abc}$ & $9.4 \mathrm{f}-\mathrm{m}$ & $9.0 \mathrm{j}-\mathrm{m}$ & $10.1 \mathrm{e}-\mathrm{k}$ \\
\hline & 2001 & Winter & $9.1 \mathrm{i}-\mathrm{m}$ & $9.6 \mathrm{f}-1$ & $10.1 \mathrm{e}-\mathrm{k}$ & $10.2 \mathrm{e}-\mathrm{k}$ & $11.5 \mathrm{de}$ \\
\hline \multirow[t]{4}{*}{ Oristano } & 2000 & Spring & $11.2 \mathrm{def}$ & $10.6 \mathrm{e}-\mathrm{j}$ & $8.1 \mathrm{lmn}$ & $10.4 \mathrm{e}-\mathrm{j}$ & $9.4 \mathrm{~g}-\mathrm{m}$ \\
\hline & 2000 & Winter & $11.0 \mathrm{~d}-\mathrm{h}$ & $14.9 \mathrm{ab}$ & $15.3 \mathrm{a}$ & $8.9 \mathrm{j}-\mathrm{m}$ & $10.4 \mathrm{e}-\mathrm{j}$ \\
\hline & 2001 & Spring & $12.5 \mathrm{~cd}$ & $9.2 \mathrm{~h}-\mathrm{m}$ & $9.2 \mathrm{~h}-\mathrm{m}$ & $10.1 \mathrm{e}-\mathrm{k}$ & $9.6 \mathrm{f}-1$ \\
\hline & 2001 & Winter & $8.0 \mathrm{lmn}$ & $7.7 \mathrm{mn}$ & $8.2 \mathrm{lmn}$ & $8.9 \mathrm{j}-\mathrm{m}$ & $7.7 \mathrm{mn}$ \\
\hline
\end{tabular}

weight (Table 3). The leaves containing the lowest polyphenols content were those of cv Tonina in the Winter of 2000 in Alghero, whereas those with the highest polyphenol content were sampled from cv Daniela in the Winter of 2000 in Oristano.

Polyphenol content in infusions ranged between 2.6 and $13.9 \mathrm{~g} \cdot \mathrm{L}^{-1}$ (Table 4 ). The highest polyphenol content was determined in leaves of cv Daniela in the Winter of 2001 in Alghero, whereas the lowest content was recorded for cv Marta in the Winter of 2000 in Oristano.

Color of infusions. Color components of the hydroalcoholic infusions showed few differences among the different samples: $\mathrm{L}^{*}$ (brightness) ranged between 49.94 and 44.22; $\mathrm{a}^{*}$ (green-red) varied from -5.82 to -2.50 ; and $b^{*}$ (blue-yellow) ranged between 10.74 and 18.40 (Table 5). All factors influenced the chromatic components of the infusion color except for season for the parameter $a^{*}$ (Table 5). However, the occurrence of significant interactions among all studied factors did not allow for the definition of a clear influence of year, season, locality, and/ or cultivar for the color characteristics of infusions, similar to other studied parameters.

\section{Discussion}

The sources of variability considered in the present study had variable influences on the composition of leaves and their relative infusions. However, the interpretation of their single effects is complex because of the existing interactions among them.

Among the different myrtle cultivars, low variability was recorded for leaf composition, especially for tannin and total polyphenol 
Table 4. Tannins and polyphenols content in infusions of myrtle leaves from cultivated plants. Each value is the mean of three replications. Mean separation was performed by Duncan's multiple range test. Data labeled with the same letter are not significantly different at $P \leq 0.01$.

\begin{tabular}{|c|c|c|c|c|c|c|c|}
\hline \multicolumn{8}{|c|}{ Tannins (mg. $\mathrm{L}^{-1}$ infusion) } \\
\hline \multirow[b]{2}{*}{ Area } & \multirow[b]{2}{*}{ Yr } & \multirow[b]{2}{*}{ Season } & \multicolumn{5}{|c|}{ Cultivar } \\
\hline & & & Nadia & Marta & Daniela & Tonina & Grazia \\
\hline \multirow[t]{4}{*}{ Alghero } & 2000 & Spring & $135 \mathrm{gh}$ & 133 ghi & $103 \mathrm{k}-\mathrm{n}$ & $128 \mathrm{ghi}$ & $100 \mathrm{lmn}$ \\
\hline & 2000 & Winter & $176 \mathrm{de}$ & $145 \mathrm{fg}$ & $232 \mathrm{~b}$ & $146 \mathrm{fg}$ & $182 \mathrm{~d}$ \\
\hline & 2001 & Spring & $118 \mathrm{~h}-1$ & $124 \mathrm{hij}$ & $108 \mathrm{jkl}$ & $87 \mathrm{mno}$ & $88 \mathrm{mno}$ \\
\hline & 2001 & Winter & $205 \mathrm{c}$ & $120 \mathrm{~h}-\mathrm{k}$ & $291 \mathrm{a}$ & $147 \mathrm{fg}$ & $145 \mathrm{fg}$ \\
\hline \multirow[t]{4}{*}{ Oristano } & 2000 & Spring & $179 \mathrm{de}$ & 134 ghi & $119 \mathrm{~h}-1$ & $116 \mathrm{i}-1$ & $155 \mathrm{f}$ \\
\hline & 2000 & Winter & 81 o & $58 \mathrm{p}$ & $146 \mathrm{fg}$ & $57 \mathrm{p}$ & 85 no \\
\hline & 2001 & Spring & 162 ef & $118 \mathrm{~h}-1$ & $122 \mathrm{~h}-\mathrm{k}$ & $104 \mathrm{klm}$ & $88 \mathrm{mno}$ \\
\hline & 2001 & Winter & $182 \mathrm{~d}$ & $134 \mathrm{ghi}$ & $175 \mathrm{de}$ & $59 \mathrm{p}$ & $144 \mathrm{fg}$ \\
\hline
\end{tabular}

\begin{tabular}{llllllll}
\multirow{2}{*}{ Alghero } & \multicolumn{7}{c}{ Polyphenols $\left(\mathrm{g} \cdot \mathrm{L}^{-1}\right.$ infusion $)$} \\
& 2000 & Spring & $7.2 \mathrm{f}-\mathrm{k}$ & $8.3 \mathrm{~d}-\mathrm{g}$ & $6.5 \mathrm{k}-\mathrm{p}$ & $6.6 \mathrm{j}-\mathrm{o}$ & $5.6 \mathrm{n}-\mathrm{q}$ \\
& 2000 & Winter & $6.1 \mathrm{k}-\mathrm{p}$ & $5.9 \mathrm{l}-\mathrm{p}$ & $7.8 \mathrm{e}-\mathrm{j}$ & $4.5 \mathrm{q}$ & $5.2 \mathrm{pq}$ \\
\multirow{5}{*}{ Oristano } & 2001 & Spring & $8.1 \mathrm{~d}-\mathrm{h}$ & $11.3 \mathrm{c}$ & $8.3 \mathrm{~d}-\mathrm{g}$ & $6.5 \mathrm{k}-\mathrm{p}$ & $6.8 \mathrm{i}-\mathrm{n}$ \\
& 2001 & Winter & $12.6 \mathrm{~b}$ & $8.0 \mathrm{e}-\mathrm{i}$ & $13.9 \mathrm{a}$ & $5.4 \mathrm{opq}$ & $9.3 \mathrm{~d}$ \\
& 2000 & Spring & $7.0 \mathrm{~h}-\mathrm{m}$ & $6.4 \mathrm{k}-\mathrm{p}$ & $5.9 \mathrm{l}-\mathrm{p}$ & $5.6 \mathrm{n}-\mathrm{q}$ & $5.5 \mathrm{opq}$ \\
& 2000 & Winter & $3.1 \mathrm{r}$ & $2.6 \mathrm{r}$ & $5.8 \mathrm{~m}-\mathrm{p}$ & $3.0 \mathrm{r}$ & $5.4 \mathrm{opq}$ \\
& 2001 & Spring & $8.4 \mathrm{def}$ & $8.5 \mathrm{de}$ & $8.2 \mathrm{~d}-\mathrm{h}$ & $7.8 \mathrm{e}-\mathrm{j}$ & $7.1 \mathrm{~g}-1$ \\
& 2001 & Winter & $11.2 \mathrm{c}$ & $12.9 \mathrm{ab}$ & $10.7 \mathrm{c}$ & $4.5 \mathrm{q}$ & $12.7 \mathrm{ab}$ \\
\hline
\end{tabular}

Table 5. Color evaluation in myrtle hydroalcoholic infuses by CIELAB chromatic scale. Each value is the mean of 15 replications. Mean separation was performed by Duncan's multiple range test. Data labeled with the same letter are not significantly different at $P \leq 0.01$.

\begin{tabular}{|c|c|c|c|c|c|c|c|}
\hline \multicolumn{8}{|c|}{$\mathrm{L}^{*}$} \\
\hline \multirow[b]{2}{*}{ Area } & \multirow[b]{2}{*}{$\mathrm{Yr}$} & \multirow[b]{2}{*}{ Season } & \multicolumn{5}{|c|}{ Cultivar } \\
\hline & & & Nadia & Marta & Daniela & Tonina & Grazia \\
\hline \multirow[t]{4}{*}{$\overline{\text { Alghero }}$} & 2000 & Spring & $45.37 \mathrm{pq}$ & $46.471-\mathrm{O}$ & $46.06 \mathrm{~m}-\mathrm{p}$ & $47.49 \mathrm{e}-\mathrm{i}$ & $47.39 \mathrm{f}-\mathrm{j}$ \\
\hline & 2000 & Winter & $44.67 \mathrm{rs}$ & $48.51 \mathrm{~cd}$ & $47.69 \mathrm{e}-\mathrm{h}$ & $46.161-\mathrm{o}$ & $48.57 \mathrm{~cd}$ \\
\hline & 2001 & Spring & $47.22 \mathrm{~h}-\mathrm{k}$ & 48.14 cde & $48.02 \mathrm{~d}-\mathrm{g}$ & $48.44 \mathrm{~cd}$ & $48.45 \mathrm{~cd}$ \\
\hline & 2001 & Winter & $46.70 \mathrm{j}-\mathrm{m}$ & $49.35 \mathrm{ab}$ & 45.90 nop & 45.82 op & $46.271-0$ \\
\hline \multirow[t]{4}{*}{ Oristano } & 2000 & Spring & $46.501-\mathrm{o}$ & $46.03 \mathrm{~m}-\mathrm{p}$ & $46.86 \mathrm{i}-1$ & $47.26 \mathrm{~h}-\mathrm{k}$ & $46.381-0$ \\
\hline & 2000 & Winter & $48.11 \mathrm{cde}$ & $49.31 \mathrm{ab}$ & $47.35 \mathrm{~g}-\mathrm{j}$ & $49.94 \mathrm{a}$ & $49.51 \mathrm{a}$ \\
\hline & 2001 & Spring & $46.58 \mathrm{k}-\mathrm{n}$ & $47.89 \mathrm{~d}-\mathrm{h}$ & $48.82 \mathrm{bc}$ & $48.49 \mathrm{~cd}$ & $48.07 \mathrm{def}$ \\
\hline & 2001 & Winter & $44.22 \mathrm{~s}$ & $45.06 \mathrm{qr}$ & $45.41 \mathrm{pq}$ & $48.11 \mathrm{cde}$ & $46.311-0$ \\
\hline \multicolumn{8}{|c|}{$\mathrm{a}^{*}$} \\
\hline \multirow[t]{4}{*}{ Alghero } & 2000 & Spring & $-3.36 \mathrm{~d}$ & $-3.92 \mathrm{fgh}$ & $-3.69 \mathrm{ef}$ & $-4.02 \mathrm{~g}-\mathrm{j}$ & $-3.02 \mathrm{~b}$ \\
\hline & 2000 & Winter & $-3.31 \mathrm{~cd}$ & $-3.85 \mathrm{fg}$ & $-3.99 \mathrm{f}-\mathrm{i}$ & $-3.47 \mathrm{de}$ & $-4.28 \mathrm{i}-\mathrm{m}$ \\
\hline & 2001 & Spring & $-4.39 \mathrm{k}-\mathrm{n}$ & $-3.93 \mathrm{fgh}$ & $-4.97 \mathrm{p}$ & $-4.421 \mathrm{lmn}$ & $-5.02 \mathrm{p}$ \\
\hline & 2001 & Winter & $-4.16 \mathrm{~g}-1$ & $-5.82 \mathrm{q}$ & $-4.21 \mathrm{~h}-\mathrm{m}$ & $-4.29 j-m$ & $-4.10 \mathrm{~g}-\mathrm{k}$ \\
\hline \multirow[t]{4}{*}{ Oristano } & 2000 & Spring & $-2.94 \mathrm{~b}$ & $-3.41 \mathrm{de}$ & $-3.33 \mathrm{~cd}$ & $-3.93 \mathrm{fgh}$ & $-3.94 \mathrm{fgh}$ \\
\hline & 2000 & Winter & $-4.46 \mathrm{lmn}$ & -4.60 no & $-3.06 b c$ & $-4.50 \mathrm{mno}$ & $-3.96 \mathrm{fgh}$ \\
\hline & 2001 & Spring & $-3.50 \mathrm{de}$ & $-3.86 \mathrm{fg}$ & $-4.29 j-m$ & -4.61 no & $-4.41 \mathrm{lmn}$ \\
\hline & 2001 & Winter & $-3.22 \mathrm{bcd}$ & $-2.50 \mathrm{a}$ & $-3.43 \mathrm{de}$ & -4.77 op & $-3.50 \mathrm{de}$ \\
\hline \multicolumn{8}{|c|}{$b^{*}$} \\
\hline \multirow[t]{4}{*}{ Alghero } & 2000 & Spring & $13.23 \mathrm{n}-\mathrm{q}$ & $13.42 \mathrm{~m}-\mathrm{q}$ & $12.37 \mathrm{qr}$ & $12.51 \mathrm{pq}$ & $10.74 \mathrm{~s}$ \\
\hline & 2000 & Winter & $15.46 \mathrm{~d}-\mathrm{i}^{\mathrm{i}}$ & $16.44 \mathrm{c}-\mathrm{f}$ & $16.10 \mathrm{~d}-\mathrm{g}$ & $17.68 \mathrm{ab}$ & $17.26 \mathrm{bc}$ \\
\hline & 2001 & Spring & $16.59 \mathrm{~cd}$ & $14.84 \mathrm{~h}-\mathrm{k}$ & $15.64 \mathrm{~d}-\mathrm{i}$ & $14.20 \mathrm{k}-\mathrm{n}$ & $16.50 \mathrm{cde}$ \\
\hline & 2001 & Winter & $15.84 \mathrm{~d}-\mathrm{h}$ & $18.40 \mathrm{a}$ & $15.81 \mathrm{~d}-\mathrm{h}$ & $15.08 \mathrm{~g}-\mathrm{k}$ & $15.72 \mathrm{~d}-\mathrm{h}$ \\
\hline \multirow[t]{4}{*}{ Oristano } & 2000 & Spring & $11.21 \mathrm{~s}$ & $12.98 \mathrm{opq}$ & $11.47 \mathrm{rs}$ & $13.09 \mathrm{opq}$ & $14.29 \mathrm{j}-\mathrm{m}$ \\
\hline & 2000 & Winter & $16.44 \mathrm{c}-\mathrm{f}$ & $15.21 \mathrm{~g}-\mathrm{k}$ & $15.15 \mathrm{~g}-\mathrm{k}$ & $14.54 \mathrm{i}-1$ & 16.49 cde \\
\hline & 2001 & Spring & $15.37 \mathrm{e}-\mathrm{j}$ & $15.48 \mathrm{~d}-\mathrm{i}$ & $14.95 \mathrm{~h}-\mathrm{k}$ & $15.34 \mathrm{f}-\mathrm{j}$ & $16.34 \mathrm{c}-\mathrm{f}$ \\
\hline & 2001 & Winter & $13.621-0$ & $13.48 \mathrm{~m}-\mathrm{p}$ & $14.95 \mathrm{~h}-\mathrm{k}$ & $16.11 \mathrm{~d}-\mathrm{g}$ & $16.16 \mathrm{~d}-\mathrm{g}$ \\
\hline
\end{tabular}

contents, whereas wider differences were observed for chlorophylls. Differences in leaf composition seemed to be influenced by the year of harvest. Growing location was the least influential variable on the polyphenol content of leaves, but a few differences were also determined by the sampling season, particularly for the tannin content of leaves.

Spring leaves are considered more suitable for processing because they are less fibrous and contain more aromatic compounds than winter leaves. However, leaves promote myrtle domestication and the attempts to improve the mechanical harvest of the berries, these findings are important. In fact, because the mechanical harvest of myrtle berries causes a partial defoliation, the leaf biomass may be easily recovered and processed for white myrtle liqueur production (Mulas et al., 2002a).

As observed for red myrtle liqueur obtained by berry infusion (Franco et al., 1998), the industrial processing and infusion dilution have a remarkable influence on the final characteristics of white myrtle liqueur. The observed differences in composition among the various raw materials were only partially transmitted to the corresponding hydroalcoholic infusions. Moreover, all the calculated correlations between the analyzed compounds of leaves and those of infusions were not statistically significant, except for polyphenols, which showed a low correlation anyway (Table 6). This is probably a consequence of differences in the solubility of the analyzed compounds in the hydroalcoholic solution and of the process of transformation and degradation occurring during the first months of infusion. For instance, leaf blade size and its anatomical structure (epidermis and cuticle thickness) may have an important role in the solubilization of the analyzed components in the hydroalcoholic infusion.

In the few last years, some researchers have focused their attention on the antioxidant properties of some myrtle extracts (Romani et al., 2004; Rosa et al., 2003). They found that hydroalcoholic extracts containing galloyl-glycosides, ellagitannins, galloylquinic acids, and flavonol-glycosides had a powerful antioxidant activity. Moreover, Alamanni and Cossu (2004), testing the radical scavenging activity and antioxidant activity of myrtle liqueurs, found that the samples with the higher phenol content showed the higher free radical scavenging activity and antioxidant activity.

Apart from their potentially beneficial health effects, it is known that tannins and polyphenols are generally involved in the bitter taste and astringency of foods and drinks, as well as in their color, together with chlorophylls. Unfortunately, some polyphenols produce an irreversible turbidity in bottled beverages. Therefore, high polyphenol content is undesirable to obtain a high physical stability in some drinks (e.g., beers and wines). The muddy appearance of myrtle leaf infusions and liqueurs may be because of their high phenol content.

The dark color of leaf hydroalcoholic infusions $\left(\mathrm{L}^{*}\right)$ seemed not to be related with leaf chlorophyll content (Table 6). However, the negative correlations found between infusion $\mathrm{L}^{*}$ and infusion content of chlorophylls, tannins, and polyphenols clearly indicate that those components as responsible for the pale brown color of myrtle infusion. The other two color components ( $a^{*}$ and $b^{*}$ ) showed low correlations with other leaf and infusion compounds, but were correlated between themselves and with the $\mathrm{L}^{*}$ parameter, especially for $\mathrm{a}^{*}$. 
The green (i.e., more negative $a^{*}$ values) and yellow (i.e., more negative $b^{*}$ values) components of the color of the infusions prevailed in all samples. High concentrations of chlorophylls, tannins, and polyphenols determined a darker and less green color, with a light increase of yellow-brown components.

Finally, the lack of relevant differences among cultivars for the analyzed compounds may be considered a positive finding, in the perspective of an easy standardization of the industrial production of liqueurs and for the assurance of a good quality of the final product.

\section{Literature Cited}

Alamanni, M.C. and M. Cossu. 2004. Radical scavenging activity and antioxidant activity of liquors of myrtle (Myrtus communis L.) berries and leaves. Italian J. Food Sci. 16:197-208.

Al-Saimary, I.E., S.S. Bakr, T. Jaffar, A.E. AlSaimary, H. Salim, and R. Al-Muosawi. 2002. Effects of some plant extracts and antibiotics on Pseudomonas aeruginosa isolated from various burn cases. Saudi Med. J. 23(7):802-805.

Boelens, M.H. and R. Jimenez. 1992. The chemical composition of Spanish Myrtle Oils. Part II. J. Essent. Oil Res. 4:349-353.

Bradesi, P., F. Tomi, J. Casanova, J. Costa, and A.F. Bernardini. 1997. Chemical composition of Myrtle leaf essential oil from Corsica (France). J. Essent. Oil Res. 9:283-288.

Commission Internationale de l'Eclairage. 1976. Recommendation on uniform color space-color difference equations, psychometric color terms. Suppl. 2 to CIE, Publ. No. 15 (E-1.3.1) 1971/(TC-1-3), Paris, France.

Congiu, F. and A. Franco. 1998. Caratterizzazione della frazione antocianica e degli acidi organici in Myrtus communis L. Collana di Studi "I mirto di Sardegna Tradizionale.” Cagliari (Italy) $: 7-60$.

Demo, A., C. Petrakis, P. Kefalas, and D. Boskou. 1998. Nutrient antioxidant in some herbs and Mediterranean plant leaves. Food Res. Intl. 31(5):351-354.

Dorman, H.J.D. and S.G. Deans. 2000. Antimicrobial agents from plants: Antibacterial activity of plant volatile oils. J. Appl. Microbiol. $88: 308-316$

Dulger, B. and A. Gonuz. 2004. Antimicrobial activity of certain plants used in Turkish traditional medicine. Asian J. Plant Sci. 3(1):104-107.

Franco, M.A., G. Versini, F. Mattivi, A. Dalla Serra, V. Vacca, and G. Manca. 1998. Analisi chimico-merceologica della bacche di mirto, dei semilavorati e dei liquori al commercio, p. 123-263. In: Caratterizzazione del liquore Mirto di Sardegna tradizionale. Aspetti storici, geografici, tecnico economico-gestionali e chimico merceologici. Consorzio 21, Cagliari. Italy

Gauthier, R., M. Gourai, and J. Bellakkhdar. 1988 A propos de l'huile essentielle de Myrtus communis L. var. italica recolte au Maroc. I. Rendements et composition during un vegetatif annuel. Al Biruniya Rev. March Pharm. 4:97-116.

Hinou, J., N. Lakkas, and S. Philianos. 1988. Les constituants polyphenoliques de Myrtus communis L. Plantes médicinales et phytotérapie. Tome XXII(2):98-103.
Inskeeo, W.P. and P.R. Bloom. 1985. Extinction coefficients of chlorophyll $a$ and $b$ in $\mathrm{N}, \mathrm{N}$, dimethyl-formamide and $80 \%$ acetone. Plant Physiol. 77:483-485.

Milhau, G., A. Valentin, F. Benoit, M. Mallié, J.M Bastide, Y. Pellissier, and J.M. Bessiere. 1997. In vitro antimalarial activity of eight essential oils. J. Essent. Oil Res. 9:329-333.

Mulas, M., M.R. Cani, and N. Brigaglia. 1998. Characters useful to cultivation in spontaneous populations of Myrtus communis L. Acta Hort. 457:271-278.

Mulas, M. and M.R. Cani. 1999. Germplasm evaluation of spontaneous myrtle (Myrtus communis L.) for cultivar selection and crop development. J. Herbs. Spices Med. Plants 6(3):31-49.

Mulas, M., M.R. Cani, N. Brigaglia, and P. Deidda 1999. Study of myrtle (Myrtus communis L.) genetic resources to promote extensive crop as integration of spontaneous harvests. Acta Hort. 502:85-88.

Mulas, M., A.H.D. Francesconi, and B. Perinu. 2002a. Myrtle (Myrtus communis L.) as a new aromatic crop: Cultivar selection. J. Herbs Spices Med. Plants. 9:127-131.

Mulas, M., A.H.D. Francesconi, B. Perinu, and A. Fadda. 2002b. 'Barbara' and 'Daniela': Two cultivars for myrtle berries production. Acta Hort. 576:169-175.

Özcan, M. and J.C. Chalchat 2004. Effect of collection period on the flavour profiles of the leaves of myrtle tree (Myrtus communis L.) growing wild in Turkey. Res. J. Chem. Environ. 8:84-93.

Romani, A., R. Coinu, S. Carta, P. Pinelli, C. Galardi, F.F. Vincieri, and F. Franconi. 2004 Evaluation of antioxidant effect of different extracts of Myrtus communis L. Free Radic. Res. 38:97-103.

Romani, A., P. Pinelli, N. Mulinacci, F.F. Vincieri, and M. Tattini. 1999. Identification and quantification of polyphenols in leaves of Myrtus communis.. Chromatographia 49:17-20.

Rosa, A., M. Deiana, V. Casu, G. Corona, G. Appendino, F. Bianchi, M. Ballero, and A.M. Dessì. 2003. Antioxidant activity of olygomeric acyphloroglucinols from Myrtus communis L. Free Radic. Res. 37:1013-1019.

Shadidi Bonjar, G.H. 2004. Antibacterial screening of plants used in Iranian folkloric medicine. Fitoterapia 75:231-235.

Shadidi Bonjar, G.H. and N.A. Karimi. 2004. Antibacterial activity of some medicinal plants of Iran against Pseudomonas aeruginosa and Pseudomonas fluorescens. Asian J. Plant Sci. 3:61-64.

Traboulsi, A.F., K. Taoubi, S. El-Haj, J.M. Bessiere, and S. Rammal. 2002. Insecticidal properties of essential plant oils against the mosquito Culex pipiens molestus (Diptera: Culicidae). Pest Mgt. Sci. 58(5):491-495.

Vanhaelen, M. and R. Vanhaelen-Fastré. 1980 Constituents of essential oil of Myrtus communis L. J. Med. Plant Res. 39:164-167.

Weyerstahl, P., H. Marschall, and A. Rustaiyan. 1994. Constituents of the essential oil of Myrtus communis L. from Iran. Flavour Fragrance J. 9:333-337.

Zolfaghari, M.E., P. Salamian, A. Riazi, and G. Khaksa. 1997. Clinical trial of efficacy of myrtle oil in the treatment of Herpes simplex. Iranian J. Med. Sci. 22:137-139. 